\title{
Energy Homoeostasis: The Roles of Adipose Tissue- Derived Hormones, Peptide YY and Ghrelin
}

\author{
Jocelin Hall ${ }^{a}$ Rachel Roberts ${ }^{a} \quad$ Niral Vora $^{b}$ \\ a School of Medicine, King's College London, \\ ${ }^{b}$ University College London, UK
}

\section{Key Words}

Adipose tissue - Appetite - Diabetes mellitus . Insulin resistance Obesity

\section{Summary}

This review discusses the physiology of the hormones leptin, adiponectin, resistin, peptide $Y Y$, and ghrelin and how each of these contributes to energy homoeostasis, weight regulation, and the pathogenesis of obesity. The relationship these hormones have with insulin and insulin resistance is also discussed, and the potential therapeutic use of each of these hormones is also considered.

\section{Introduction}

Obesity is a growing concern, which the World Health Organisation predicts will affect 700 million people by 2015 [1]. Adipose tissue has been established as a complex endocrine organ, secreting leptin, adiponectin, and resistin, which regulate long-term satiety, appetite, and energy expenditure. Gut hormones play an integral role in short-term appetite control. Ghrelin is the only known gut hormone to stimulate appetite while peptide YY (PYY), glucagon-like peptide-1, cholecystokinin, and oxyntomodulin suppress appetite. Of the hormones that suppress appetite, PYY has attracted particular interest in recent years and will therefore form the basis of our discussion of short-term appetite suppression. This relatively new area of endocrinology is likely to offer better understanding of obesity and potential therapeutic options for obesity and obesity-related morbidities. This review focuses on the specific role these hormones have in energy homoeostasis (fig. 1).

\author{
Long-Term Control
}

\section{Leptin}

The existence of circulating factors produced in the periphery that changed in relation to body fat stores and that were capable of signalling energy stores in the central nervous system were first postulated by Kennedy [2]. Insulin was the first peripheral hormone to be identified as important in energy homoeostasis [3], however, evidence for another hormone came from a series of classic parabioses studies carried out in mice by Coleman in the early 1970s [4]. A putative factor was discovered 2 decades later by Zhang et al. [5], who first identified leptin through positional cloning of the obese (ob) gene in mice. Leptin, derived from the Greek word 'leptos', meaning 'thin', is a $16 \mathrm{kDa}$ product of the ob gene produced primarily by adipocytes [5]. Lack of a functional gene in ob/ ob mice leads to hyperphagia and severe obesity [5]. Diabetic (db) db/db mice which also share a similar phenotype lack a functional leptin receptor, being leptin-resistant [6]. The role of leptin in energy homoeostasis (fig. 2) is best emphasised by the observation that the characteristic features of congenital leptin deficiency in humans, which in addition to severe childhood obesity include delayed maturation of the reproductive system and immune dysfunction, are all subsequently ameliorated by daily therapy with recombinant leptin [7, 8], suggesting a role for this adipokine in reproduction and immune function.

Leptin exerts its biological activity by binding to the leptin receptor (LR), of which 6 variants have been identified in mice, classified from a to $\mathrm{f}$ [9]. LRb, a type 1 cytokine cell surface receptor, is the only variant that possesses an intracellular domain and is therefore capable of mediating cell signalling (when dimerised) via the recruitment of janus-associated kinase 2 (JAK2), a cytoplasmic tyrosine kinase [10]. Autophosphorylation of JAK and phosphorylation of a select

\section{KARGER}

Fax +497614520714

Information@Karger.de

www.karger.com (c) 2009 S. Karger GmbH, Freiburg

Accessible online at:

www.karger.com/ofa 


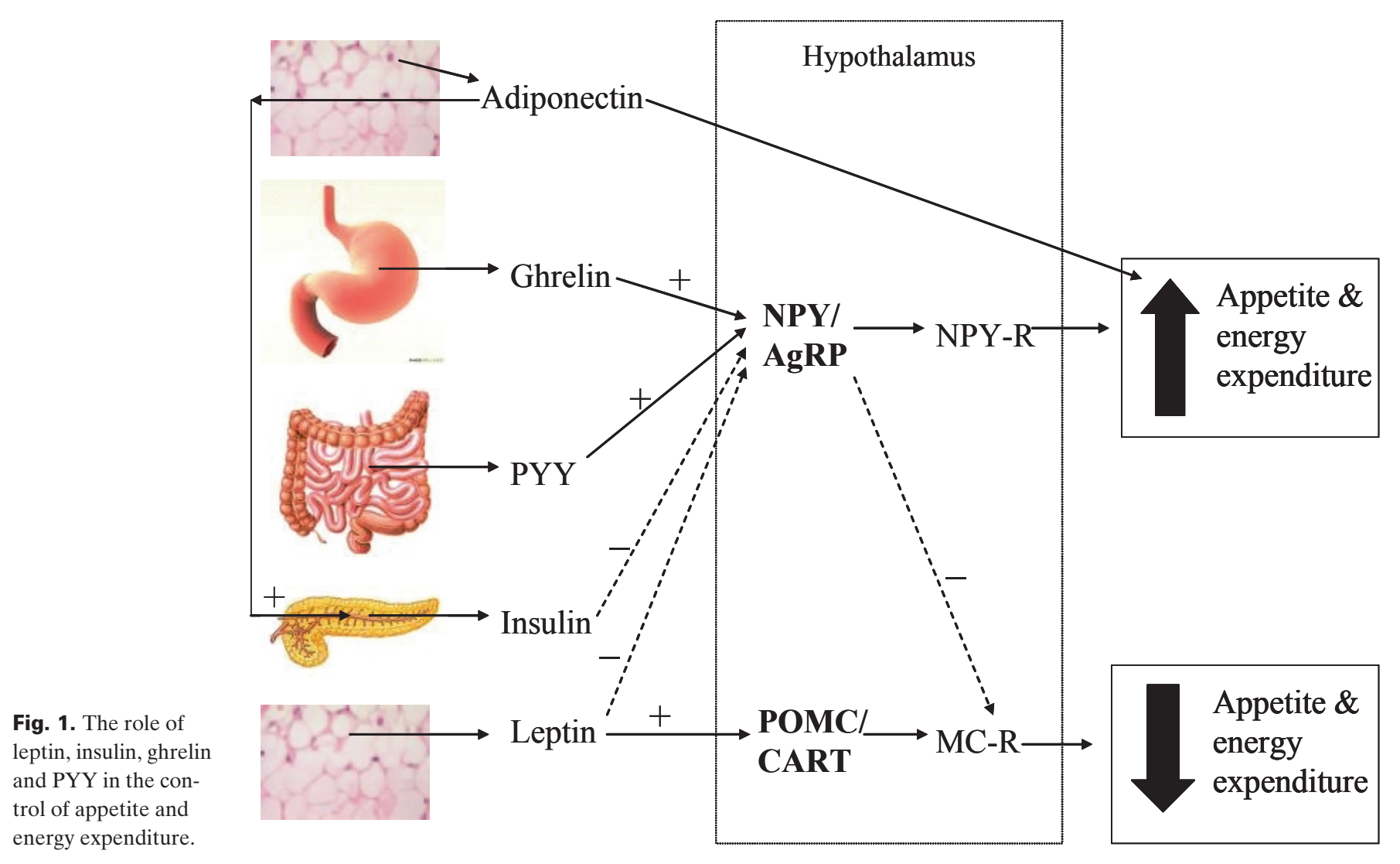

number of highly conserved tyrosine residues on LRb subsequently leads to the recruitment and phosphorylation of signal transducer and activation of transcription 3 (STAT3), a principal transcription factor [10] which in a homodimerised form regulates most of leptin's bioactivities. In addition, an elegant mechanism exists whereby the intracellular signal is terminated through the up-regulation of the suppressor of cytokine signalling 3 (SOCS3) molecule, which may play a role in mediating leptin resistance $[11,12]$. This has been demonstrated in mice that are haploinsufficient for the SOCS3 gene and that have improved leptin and insulin sensitivity compared to wildtype mice [11]. Moreover, a similar effect is observed in mice that are SOCS3-deficient in their brains [12]. Complete absence of the SOCS3 gene is incompatible with life [11]. It must also be noted that both the phosphoinositide-3 kinase (PI-3K) and extracellular signal-regulated protein kinase (ERK) pathways have also been implicated in LRb signalling [13].

Several tissues expressing the LR have been identified and include the liver and pancreas as well as cells of the immune system [14]. However, the most significant site of leptin action occurs in the brain, particularly in the hypothalamus. Cohen et al. [15] elegantly demonstrated that induced loss of LR in the brain leads to obesity. Brain-specific expression of a functional LR ameliorates obesity in the $\mathrm{db} / \mathrm{db}$ mouse that lacks a functional LR [16]. More specifically, LR-deficient Koletsky rats which have undergone targeted gene therapy and are subsequently able to express functional LRs in the arcuate nu- cleus (ARC) of the hypothalamus are rescued from the obese phenotype [17].

Leptin mediates its effect on satiety and weight reduction through its ability to regulate levels of hypothalamic neuropeptides within specific neurons of the ARC. Leptin inhibits agouti-related protein(AgRP)- and neuropeptide $\mathrm{Y}(\mathrm{NPY})$ containing neurons, which are orexigenic [9]. It also stimulates pro-opiomelanocortin(POMC)-containing neurons, which are anorexigenic and also promote energy expenditure [9]. POMC neurons may play a pivotal role in energy balance, as selected deletion of LRs on POMC neurons leads to obesity [18]. More recently, other leptin-sensitive regions have been identified within the central nervous system. This largely includes the dopaminergic neuron-rich regions of the ventral tegmental area, which may also form part of the circuitry regulating food intake [19]. Leptin also demonstrates a positive effect on locomotor activity [20].

The melanocortin signalling system is central to energy homoeostasis [21]. POMC produced in the ARC undergoes tissue-specific posttranslational modification to produce $\alpha$ melanocyte stimulating hormone ( $\alpha-\mathrm{MSH}), \alpha-\mathrm{MSH}$ exerts its anorectic effects via the melanocortin-3 receptor (MC3R) and melanocortin-4 receptor (MC4R) which are widely expressed in the hypothalamus and other areas of the brain [21]. Various studies in rodents suggest that MC4R is the key effector in suppressing food intake [21]. AgRP antagonises MC4R whereas leptin stimulates it by indirectly increasing $\alpha-\mathrm{MSH}$ 


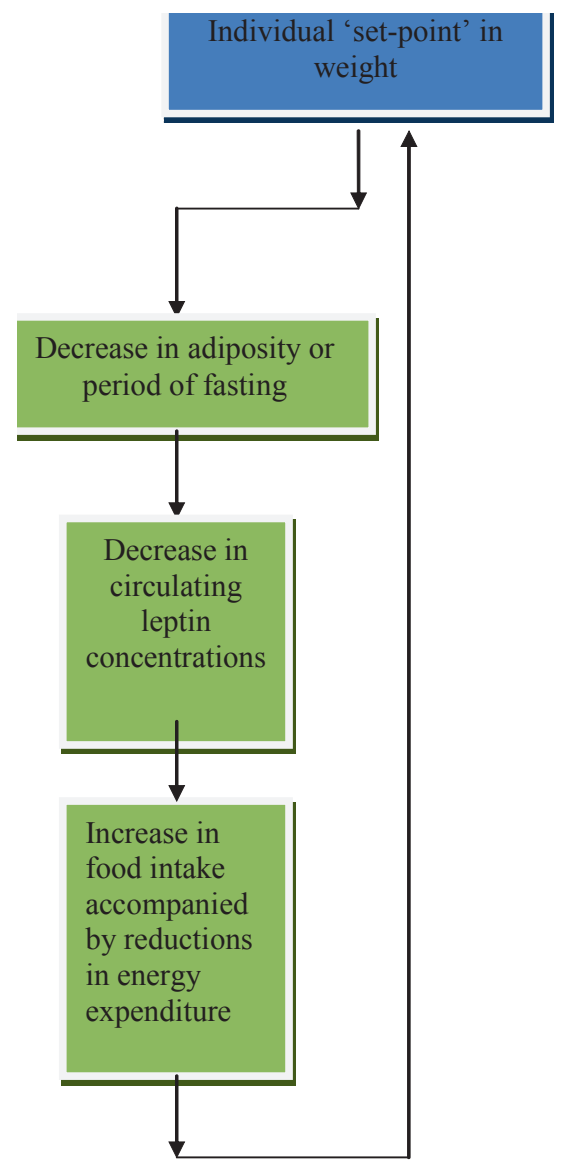

Fig. 2. Leptin - regulation of weight/feeding: A reduction in body weight from an individual 'set point' or a period of fasting is accompanied by reduced levels of circulating leptin. This results in increased food intake and a reduction in energy expenditure. This results in a normalisation of leptin concentration and/or body weight.

concentrations (achieved by increasing both POMC gene expression and action potential firing in POMC-containing neurons in the ARC) [21].

Observations from early studies in mice led to postulates placing leptin as the afferent arm of a feedback loop that signalled the brain to suppress feeding and increase energy expenditure leading to weight loss. This was based on experimental data which demonstrated significant reductions in weight and food intake in obese, leptin-deficient rodents after therapy with exogenous leptin [20,22]. Conversely, these studies demonstrated a less impressive change in weight and energy expenditure in lean rodents in which leptin is not deficient [20]. Moreover, subsequent studies in obese rodents and humans demonstrated markedly high levels of both leptin protein and leptin mRNA [23]. Leptin levels also correlate positively with fat mass [24]. As leptin promotes satiety and weight loss, the hyperleptinaemia of obesity may seem paradoxical but has been attributed to a concept known as 'leptin resistance'.

Previously, therapy utilising recombinant leptin has reduced weight and suppressed appetite in obese individuals who are deficient of leptin due to a genetic cause [25]. Mutations in the $\mathrm{Ob}$ gene are rare and tend to occur in the offspring of consanguineous marriages. Previous trials of exogenous leptin therapy in obese individuals without a genetic defect in the leptin signalling system have shown little promise [26,
27], however, more recently, Rosenbaum et al. [28] have demonstrated that leptin may have a role in maintaining reduced body weight after weight loss.

The cause of leptin resistance is still unclear but there are currently two lines of thought. Resistance may involve reduced transport of leptin across the blood-brain barrier (BBB) where it must gain access to the ARC both in animals and humans [29, 30]. Defective signalling at the post-receptor level with aberrant overactivity of SOCS3 $[11,12]$ has also been implicated. Ageing may also be an independent factor associated with acquired leptin resistance [31]. However, it is unclear as to the exact mechanism(s) responsible for leptin resistance and further work is required.

\section{Adiponectin}

Adiponectin, also known as Acrp30, AdipoQ, apM1, and GBP28, was first identified in 1995 [32]. It is a protein, coded for by a gene on chromosome $3 \mathrm{q} 27$. It is secreted by brown and white adipose tissue and circulates in the plasma in 3 major forms: a low-molecular weight (LMW), middle-molecular weight (MMW), and a high-molecular weight (HMW) [33-35]. Adiponectin functions at 2 receptors: AdipoR1, primarily in the skeletal muscle, and AdipoR2, primarily in the liver. These receptors contain 7 transmembrane domains but are distinct from G-protein-coupled receptors [36]. The effects of adiponectin have been demonstrated by adiponectin knockout (KO) mice which exhibit severe diet-induced insulin resistance, severe neo-intimal thickening in response to vascular injury, and hypertension induced by salt diet. These effects are reversible by viral-mediated production of adiponectin [37]. Consequently, adiponectin is thought to play a role in glucose and lipid metabolism and in inhibiting inflammation and atherosclerosis. More recently, it has also been suggested that adiponectin has a central effect at the arcuate hypothalamus, stimulating food intake and decreasing energy expenditure during fasting [38].

Decreased adiponectin concentrations have been shown to be associated with obesity [39] and insulin resistance [40] in mice studies, but understanding of the cause of the decrease is limited. However, in obese subjects, an increase in adipose oxidative stress with a consequent increase in reactive oxygen species [41] and cytokines [42] is thought to contribute, at least in part, to decreased adiponectin synthesis. Adiponectin affects insulin resistance by enhancing the action of insulin, with injection of adiponectin into mice triggering a transient decrease in basal glucose but no associated increase in insulin [43]. This led to the proposal that adiponectin may be involved in the pathogenesis of type 2 diabetes mellitus (T2DM). A chromosomal link to T2DM has been found in the region of the adiponectin gene [44], and certain single nucleotide polymorphisms of the adiponectin gene are associated with alterations in plasma adiponectin levels, insulin resistance, and T2DM [45]. Studies have even suggested that high levels of circulating adiponectin may result in a $40 \%$ decrease in the 
development of T2DM in certain populations [46]. Although the mechanism by which adiponectin increases insulin sensitivity has been investigated, it is not fully understood. Insulin action is initiated by the binding of insulin to its receptor, which then undergoes tyrosine phosphorylation and is activated. Downstream, the phosphatidylinositol-3 kinase (PI3K) pathway stimulates translocation of GLUT-4 transporters into the plasma membrane and therefore increases glucose uptake. Recently, the PI3K pathway has been shown to be inhibited by the target of rapamycin (TOR) complex 1-induced signalling pathway which is mediated by the S6 kinase(S6K)-dependent phosphorylation of the insulin receptor substrate-1 (IRS-1). Adiponectin affects insulin sensitivity by inhibiting the mTOR/S6K signalling pathway, thus disinhibiting the insulin signalling pathway and enhancing insulin action [47]. In addition to its insulin-sensitising properties, recent studies have also indicated that adiponectin may stimulate pancreatic insulin secretion both in vitro and in vivo [48].

Adiponectin KO mice develop neointimal thickening, and consequently adiponectin has been thought to play an important role in the development of atherosclerosis [49]. It has been proposed that in vascular endothelium injury adiponectin accumulates in the subendothelial space [50], suppressing monocyte attachment by inhibition of cell adhesion molecule1 and E-selectin [51], inhibiting vascular smooth muscle proliferation [52] and suppressing macrophage-to-foam cell formation [53]. High levels of adiponectin have been shown to be protective against the development of coronary artery disease [54]. However, in patients with pre-existing symptomatic coronary artery disease, high adiponectin concentrations are associated with an increase in cardiovascular events. This finding has led to the suggestion that adiponectin concentrations are raised in those with pre-existing disease to try and combat the pro-atherosclerotic state of the patient, although the increase is insufficient to counter the other negative factors present [55].

The HMW form of adiponectin has been found to be the most clinically relevant. Quantity of HMW adiponectin has been found to be more significant in determining insulin sensitivity [56] and coronary artery disease [57] than total adiponectin. Gene mutations that specifically impair HMW adiponectin formation have similarly been shown to be associated with T2DM [58].

The highly significant physiological role of adiponectin has caused speculation over its potential as a therapeutic target. Thiazoladinediones are the most widely recognised medications having a beneficial effect on adiponectin concentrations and have been shown to enhance insulin sensitivity at least in part by increasing circulating adiponectin concentration [59]. More recently, speculation has arisen as to whether other commonly used medication may have an impact on adiponectin concentrations. It seems likely they do, due to evidence suggesting increased adiponectin concentrations with medications such as angiotensin-converting enzyme (ACE) inhibi- tors, angiotensin II receptor blockers [60], statins, fibrates [61], and niacin (which seems to particularly increase the HMW form) [62]. Further potential therapeutic benefits of manipulating adiponectin concentrations have been speculated, and it seems likely that adiponectin may present a useful therapeutic target for combating and reversing obesity-linked diseases.

\section{Resistin}

The last adipose tissue-derived hormone described is resistin. This is a $12.5 \mathrm{kDa}$ protein that was discovered in 2001 [63] and belongs to a family of cysteine-rich proteins [64]. Secreted by adipose tissue, it circulates as a dimeric protein: 2 polypeptides linked by a disulphide bridge [65]. Its physiological role has been subject to much debate and its function remains unclear.

Associations found have suggested a link between increasing resistin and increasing adiposity $[63,66]$. Correlations between insulin resistance and resistin concentrations have also been reported in humans [67]. However, the role resistin plays in glucose homoeostasis is unclear due to conflicting studies which show decreased levels of the hormone in obesity [68, 69], the ability of thiazoladinediones to exert their antidiabetic effect without any decrease in resistin [68], and only weak correlations between resistin and insulin sensitivity [69]. Genetic variations of the resistin gene have also failed to show an association with obesity [70]. The secretion of the hormone by monocytes and macrophages may help explain the contradictory role of resistin in energy balance [71]. The conflicting data described suggest that resistin is unlikely to be revealed as a major player in the pathogenesis of T2DM and obesity.

\section{Short-Term Control}

\section{$P Y Y$}

PYY is a 36-amino acid gastrointestinal hormone, where $\mathrm{Y}$ depicts the abbreviation for tyrosine. It is a member of the pancreatic polypeptide family, which includes pancreatic polypeptide (PP) and neuropeptide Y (NPY), which mediate their effects through G-protein-linked NPY receptors of which there are several subtypes (Y1, Y2, Y4, and Y5 represent fully defined subtypes) [72]. PYY is secreted by L-cells of the distal gut, together with glucagon-like peptide and oxyntomodulin [73]. Peripheral neurons, especially enteric neurons, also express PYY, as does a restricted set of central neurons [74]. Secretion of PYY in the gastrointestinal tract is primarily stimulated by the presence of nutrients (mainly lipids and protein [75]) in the gut lumen and is proportional to the caloric density of the meal ingested [74], but is not altered by gastric distension [76]. Other stimulants of PYY release include intraluminal bile acids, gastric acid, and cholecystokinin [77]. Peak plasma levels of PYY occur in the 2nd hour following food ingestion [78].

PYY exists in 2 forms - the full-length peptide PYY136 which is truncated to the biologically active PYY3-36 by 
dipeptidyl peptidase-IV [79]. PYY3-36 is the predominant form [79] and has been shown to reduce food intake in rodents and humans [78]. PYY also inhibits transit through the proximal small intestine [80], delays gastric emptying [81], and inhibits gallbladder emptying [82]. PYY secretion stimulates vagal and somatosensory afferent fibres arising in the gastrointestinal tract and terminating at the nucleus tractus solitarius (NTS) of the brain-stem, which transmit information pertaining to recent food intake [83]. Neurons from the NTS can then relay this information to the ARC of the hypothalamus, a key component of the forebrain pathway involved in appetite control [84]. PYY can also act directly in the brain via the blood, entering at areas where the BBB is deficient [85].

PYY3-36 shows high specificity for the Y2 NPY receptor subtype (Y2R) [86] and is thought to work via activation of auto-inhibitory presynaptic Y2Rs present on orexigenic NPY neurons in the ARC [78]. These NPY neurons inhibit anorexigenic POMC neurons and therefore their inhibition by PYY336 results in reciprocal activation of POMC neurons to inhibit feeding [87]. PYY3-36 may also work by decreasing plasma ghrelin levels [88] and by inhibition of ghrelin-activated neurons of the ARC [89]. There is conflicting evidence as to whether PYY1-36 has an effect on energy intake in man [90], although data on PYY1-36 is limited.

In obese humans, fasting plasma concentrations of PYY are reduced [88] and PYY responses to a standard meal are attenuated [91], although there does not seem to be associated resistance to the effects of PYY3-36 [88], leading to the hypothesis that PYY deficiency may contribute to the pathogenesis of obesity. Genetic variations in PYY and Y2R genes may contribute to obesity and are associated with the severe obesity of Pima Indian men [92]. Furthermore, a study of a Swedish cohort has shown that the common $\mathrm{Y} 2 \mathrm{R}$ variant is less prevalent among obese compared with lean men, indicating the common Y2R variant as protective against obesity [93]. Less is known about potential changes in PYY levels in T2DM, although recently a blunted postprandial PYY response to a high carbohydrate test meal has been found in individuals genetically predisposed to T2DM [94]. The reduced PYY levels seen in obesity and prediabetes may result from abnormalities in its synthesis, release, or clearance, although it is doubtful that increased clearance plays a major role, as the rate of elimination is similar in lean and obese subjects when PYY is exogenously administrated [88]. Hypothalamic overexpression of NPY may also have a role in suppressing the anorectic effects of PYY in obese and insulin-resistant patients [95].

In contrast, PYY levels have been found to be increased in disease states characterised by significant weight loss, such as anorexia nervosa [96], coeliac disease, inflammatory bowel disease [97], and cardiac cachexia [98]. It has also been shown that after Roux-en-Y gastric bypass (RYGBP) for the treatment of morbid obesity the postprandial PYY response is exaggerated, which is thought to contribute to the weight loss and maintenance of weight loss after this procedure [99].
The relationship between insulin and PYY is controversial. As exogenous administration of PYY3-36 reinforces insulin's action on glucose uptake in mice [100] and PYY KO mice develop hyperinsulinaemia [101], it has been suggested that lower PYY levels in obesity may contribute to insulin resistance [95]. Furthermore, PYY3-36 infusions increase plasma free fatty acid concentration and subsequently increase postprandial insulin and glucose responses, as compared to saline infusion [102], implying PYY3-36 or PYY3-36-analogue treatment may be beneficial in ameliorating insulin resistance. However, the precise mechanisms by which PYY may affect insulin levels are still unclear, and some studies refute a relationship between the two $[88,103]$.

The possible use of exogenous PYY3-36 as an anti-obesity agent has provoked much interest. In humans, PYY3-36 administration has been reported to decrease both hunger and single-meal food intake by $36 \%$, without causing illness or compensatory hyperphagia [88]. A synthetic human form of PYY336 , coupled to $40 \mathrm{kDa}$ polyethylene glycol (PEG), has been created to increase the half-life of PYY3-36 from 3 to $24 \mathrm{~h}$ and has been tested in rabbits with no signs of toxicity [104]. An injectable PYY3-36 analogue was tested in phase I studies as an antiobesity therapy but had limited success due to nausea [105]. It is therefore with further research that PYY3-36 may prove to become a key player in addressing the obesity epidemic.

\section{Ghrelin}

Ghrelin is a 28-amino acid peptide produced predominantly by $\mathrm{X} / \mathrm{A}$-like cells of the mucosal layer in the fundus of the stomach [106]. Ghrelin exists in either acylated or deacylated form. Acylation of ghrelin with an O-linked octanoyl side group at serine 3 by ghrelin O-acyl transferase (GOAT), a polytopic membrane-bound enzyme, is crucial for its physiological effects [107, 108]. Ghrelin was first discovered in 1999 as a strong stimulant of growth hormone $(\mathrm{GH})$ release, and acylated ghrelin is a natural ligand of the GH secretagogue type 1a receptor (GHS-R1a) [109], which is largely expressed in the ARC of the hypothalamus [110]. In addition to stimulating GH release, ghrelin has also been identified as the only known orexigenic hormone which plays a role in regulating pre-meal hunger and meal initiation as well as long-term energy balance [111, 112]. Both peripheral and intracerebroventricular administrations of ghrelin stimulate food intake, weight gain and adiposity, and decreased energy expenditure $[113,114]$. Ghrelin's orexigenic effect is thought to occur via activation of the GHS-R1a receptor in areas such as the hypothalamus [115], although more recently it has been investigated whether des-acyl ghrelin may also induce food intake via a mechanism that is independent of the GHS-R1a [116]. It has also been shown that centrally infused ghrelin effects adipocyte metabolism independently of ghrelin-induced hyperphagia by increasing the rate of glucose utilisation by adipocytes [117]. Ghrelin also has stimulatory effects on lactotroph and corticotroph secretion [118], gastric motility [119], and cardiovascular effects [120]. 
Ghrelin synthesis and secretion are regulated by nutrient stimulation of the glutathion insulin transhydrogenase (with greater response to carbohydrate or protein ingestion compared to fat [121]) and weight loss [122]. Circulating ghrelin concentrations increase during fasting and decrease after eating [123]. In subjects on fixed feeding schedules, there is a marked surge in ghrelin before each meal, raising the possibility that anticipation of meals, in addition to effects of fasting, may also contribute to ghrelin secretion [124].

The mechanisms by which ghrelin promotes hunger and increased energy intake are not entirely clear. It is possible that the promotion of gastric emptying by ghrelin increases hunger. It has been demonstrated that gastric emptying was positively correlated with fasting plasma ghrelin levels [123]. Ghrelin also acts in the ARC of the hypothalamus to promote hunger by activating the orexigenic NPY/AgRP neurons and by antagonising the satiety effects of leptin via inhibition of POMC neurons [125]. This theory is supported by evidence that blockade of NPY receptors or immunoneutralisation of AgRP attenuates ghrelin-induced feeding. Ghrelin may gain access to the hypothalamus directly by crossing the BBB [126] or indirectly via the vagus nerve, shown by the inhibition of ghrelin's orexigenic effects following vagotomy in rats [127]. The effects of ghrelin also seem to be mediated by the sympathetic nervous system. Convincing studies have found that beta-adrenergic receptors are required for an increase in body weight to occur following central ghrelin administration [118], and a decrease in brown adipose tissue sympathetic nerve activity and lowered brown adipose tissue temperature [128] in addition to lowered core body temperature [129] in response to central ghrelin administration has also been observed.

Plasma levels of ghrelin and leptin are inversely correlated [130]. Ghrelin acts to inhibit leptin's anorexigenic effects on NPY neurons of the ARC [125], and vice versa [131]. This reciprocal relationship between leptin and ghrelin in the hypothalamus is likely to play an important role in the regulation of appetite and feeding, although the precise nature of their interaction is not entirely understood. It has been reported that the acute postprandial rises in insulin may stimulate meal-induced suppression of ghrelin [132]. Furthermore, ghrelin levels are markedly reduced in insulin-resistant subjects compared to insulin-sensitive controls, independent of BMI [133], implicating insulin as a likely candidate for ghrelin regulation.
Ghrelin levels are markedly increased in Prader-Willi syndrome and are thought to mediate the ravenous feeding in this condition [134]. However, in obese subjects fasting, plasma ghrelin levels are lower than in lean controls [135], although appetite is commonly increased, suggesting that higher body mass is associated with increased gastric responsiveness to ghrelin [136]. RYGBP has been found to successfully impair the adaptive response of ghrelin to body weight loss and is thought to contribute to the ability of patients to maintain weight loss after this procedure [137]. There has been considerable interest in the potential therapeutic uses of ghrelin and ghrelin receptor ligands. The use of ghrelin administration and GHS-R1a agonists in aiding weight gain in cachexia and anorexia nervosa has been investigated $[138,139]$. Conversely, the use of GHS-R1a antagonists in the treatment of obesity has also been explored, with antagonists such as 2,4-diaminopyrimidine showing promising results in decreasing appetite in animals [140]. However, in order to realise the full potential of ghrelin antagonism as anti-obesity treatment, GHS-R1a antagonists with better selectivity, potency, and pharmacokinetic properties are required [141].

\section{Conclusion}

It seems likely that adipokines and gut hormones both have a role to play in the pathogenesis of obesity and obesity-related morbidities, with correlations between them being found. However, clinical applications for these hormones so far remain limited, with only leptin administration showing efficacy in reversing obesity in certain leptin-deficient patients. However, with further clarification of their roles in health it seems likely that adipokines and gut hormones could offer valuable therapeutic approaches to obesity and its related morbidities.

\section{Acknowledgements}

With grateful thanks to Dr Alaghband-Zadeh and Dr Le Roux, and to the independent reviewers.

\section{Disclosure}

The authors declared no conflict of interest.

\section{References}

1 WHO (ed): Obesity and Overweight: Fact sheet No 3111. WHO, 2006. www.who.int/mediacentre/ factsheets/fs311/en/index.html.

$\checkmark 2$ Kennedy GC: The role of depot fat in the hypothalamic control of food intake in the rat. Proc R Soc Lond B Biol Sci 1953;140:578-596.
Woods SC, Porte D Jr: The central nervous system, pancreatic hormones, feeding, and obesity. Adv Metab Disord 1978;9:283-312.

4 Coleman DL: Effects of parabiosis of obese with diabetes and normal mice. Diabetologia 1973;9:294298.

5 Zhang Y, Proenca R, Maffei M, Barone M, Leopold L, Friedman JM: Positional cloning of the mouse obese gene and its human homologue. Nature 1994;372:425-432.
6 Lee GH, Proenca R, Montez JM, Carroll KM, Darvishzadeh JG, Lee JI, Friedman JM: Abnormal splicing of the leptin receptor in diabetic mice. Nature 1996;379:632-635.

7 Farooqi IS, Jebb SA, Langmack G, Lawrence E, Cheetham CH, Prentice AM, Hughes IA, McCamish MA, O'Rahilly S: Effects of recombinant leptin therapy in a child with congenital leptin deficiency. N Engl J Med 1999;341:879-884. 
8 Farooqi IS, Matarese G, Lord GM, Keogh JM, Lawrence E, Agwu C, Sanna V, Jebb SA, Perna F, Fontana S, Lechler RI, DePaoli AM, O'Rahilly S: Beneficial effects of leptin on obesity, T cell hyporesponsiveness, and neuroendocrine/metabolic dysfunction of human congenital leptin deficiency. J Clin Invest 2002:110:1093-1103.

$\checkmark 9$ Ahima RS, Osei SY: Leptin signalling. Physiol Behav 2004;81:223-241.

10 Kloek C, Haq AK, Dunn SL, Lavery HJ, Banks AS, Myers MG Jr: Regulation of Jak kinases by intracellular leptin receptor sequences. J Biol Chem 2002;277:41547-41555.

-11 Howard JK, Cave BJ, Oksanen LJ, Tzameli I, Bjørbaek C, Flier JS: Enhanced leptin sensitivity and attenuation of diet-induced obesity in mice with haploinsufficiency of Socs3. Nat Med 2004;10:734-738.

-12 Mori H, Hanada R, Hanada T, Aki D, Mashima R, Nishinakamura H, Torisu T, Chien KR, Yasukawa $\mathrm{H}$, Yoshimura A: Socs 3 deficiency in the brain elevates leptin sensitivity and confers resistance to diet-induced obesity. Nat Med 2004;10:739-743.

13 Robertson SA, Leinninger GM, Myers MG Jr: Molecular and neural mediators of leptin action. Physiol Behav 2008;94:637-642.

14 Bjørbaek C, Kahn BB: Leptin signalling in the central nervous system and the periphery. Recent Prog Horm Res 2004;59:305-331.

15 Cohen P, Zhao C, Cai X, Montez JM, Rohani SC, Feinstein P, Mombaerts P, Friedman JM: Selective deletion of leptin receptor in neurons leads to obesity. J Clin Invest 2001;108:1113-1121.

\16 Kowalski TJ, Liu SM, Leibel RL, Chua SC Jr: Transgenic complementation of leptin-receptor deficiency. I. Rescue of the obesity/diabetes phenotype of LEPR-null mice expressing a LEPR-B transgene. Diabetes 2001;50:425-435.

17 Morton GJ, Niswender KD, Rhodes CJ, Myers MG Jr, Blevins JE, Baskin DG, Schwartz MW: Arcuate nucleus-specific leptin receptor gene therapy attenuates the obesity phenotype of Koletsky (fa(k)/ $\mathrm{fa}(\mathrm{k}))$ rats. Endocrinology 2003;144:2016-2024.

-18 Balthasar N, Coppari R, McMinn J, Liu SM, Lee CE, Tang V, Kenny CD, McGovern RA, Chua SC $\mathrm{Jr}$, Elmquist JK, Lowell BB: Leptin receptor signalling in POMC neurons is required for normal body weight homeostasis. Neuron 2004;42:983-991.

19 Hommel JD, Trinko R, Sears RM, Georgescu D, Liu ZW, Gao XB, Thurmon JJ, Marinelli M, DiLeone RJ: Leptin receptor signalling in midbrain dopamine neurons regulates feeding. Neuron 2006;51:801-810.

20 Pelleymounter MA, Cullen MJ, Baker MB, Hecht R, Winters D, Boone T, Collins F: Effects of the obese gene product on body weight regulation in ob/ob mice. Science 1995;269:540-543.

21 Shimizu H, Inoue K, Mori M: The leptin-dependent and -independent melanocortin signaling system: regulation of feeding and energy expenditure. J Endocrinol 2007;193:1-9.

22 Halaas JL, Gajiwala KS, Maffei M, Cohen SL, Chait BT, Rabinowitz D, Lallone RL, Burley SK, Friedman JM: Weight-reducing effects of the plasma protein encoded by the obese gene. Science 1995;269:543-546.

23 Maffei M, Halaas J, Ravussin E, Pratley RE, Lee GH, Zhang Y, Fei H, Kim S, Lallone R, Ranganathan S, Kern PA, Friedman JM: Leptin levels in human and rodent: measurement of plasma leptin and ob RNA in obese and weight-reduced subjects. Nat Med 1995;1:1155-1161.

-24 Considine RV, Sinha MK, Heiman ML, Kriauciunas A, Stephens TW, Nyce MR, Ohannesian JP, Marco CC, McKee LJ, Bauer TL: Serum immunoreactive-leptin concentrations in normal-weight and obese humans. N Engl J Med 1996;334:292-295.
5 Licinio J, Caglayan S, Ozata M, Yildiz BO, de Miranda PB, O'Kirwan F, Whitby R, Liang L, Cohen P, Bhasin S, Krauss RM, Veldhuis JD, Wagner AJ, DePaoli AM, McCann SM, Wong ML: Phenotypic effects of leptin replacement on morbid obesity, diabetes mellitus, hypogonadism, and behaviour in leptin-deficient adults. Proc Natl Acad Sci U S A 2004;101:4531-4536.

26 Westerterp-Plantenga MS, Saris WH, Hukshorn CJ, Campfield LA: Effects of weekly administration of pegylated recombinant human OB protein on appetite profile and energy metabolism in obese men. Am J Clin Nutr 2001;74:426-434.

27 Hukshorn CJ, Saris WH, Westerterp-Plantenga MS, Farid AR, Smith FJ, Campfield LA: Weekly subcutaneous pegylated recombinant native human leptin (PEG-OB) administration in obese men. J Clin Endocrinol Metab 2000;85:4003-4009.

28 Rosenbaum M, Sy M, Pavlovich K, Leibel RL, Hirsch $\mathrm{J}$ : Leptin reverses weight loss-induced changes in regional neural activity responses to visual food stimuli. J Clin Invest 2008;118:2583-2591.

29 Caro JF, Kolaczynski JW, Nyce MR, Ohannesian JP, Opentanova I, Goldman WH, Lynn RB, Zhang PL, Sinha MK, Considine RV: Decreased cerebrospinal-fluid/serum leptin ratio in obesity: a possible mechanism for leptin resistance. Lancet 1996:348:159-61.

30 Levin BE, Dunn-Meynell AA, Banks WA: Obesity-prone rats have normal blood-brain barrier transport but defective central leptin signalling before obesity onset. Am J Physiol Regul Integr Comp Physiol 2004;286:R143-150.

31 Gabriely I, Ma XH, Yang XM, Rossetti L, Barzilai $\mathrm{N}$ : Leptin resistance during aging is independent of fat mass. Diabetes 2002:51:1016-1021.

- 32 Scherer PE, Williams S, Fogliano M, Baldini G, Lodish HF: A novel serum protein similar to $\mathrm{C} 1 \mathrm{q}$, produced exclusively in adipocytes. J Biol Chem 1995;270:26746-26749.

33 Pajvani UB, Du X, Combs TP, Berg AH, Rajala MW, Schulthess T, Engel J, Brownlee M, Scherer PE: Structure-function studies of the adipocyte-secreted hormone Acrp30/adiponectin: implications for metabolic regulation and bioactivity. J Biol Chem 2003;278:9073-9085.

34 Tsao TS, Tomas E, Murrey HE, Hug C, Lee DH, Ruderman NB, Heuser JE, Lodish HF: Role of disulfide bonds in Acrp30/adiponectin structure and signalling specificity: different oligomers activate different signal transduction pathways. J Biol Chem 2003;278:50810-50817.

35 Waki H, Yamauchi T, Kamon J, Ito Y, Uchida S, Kita S, Hara K, Hada Y, Vasseur F, Froguel P, Kimura S, Nagai R, Kadowaki T: Impaired multimerization of human adiponectin mutants associated with diabetes: molecular structure and multimer formation of adiponectin. J Biol Chem 2003;278:40352-40363.

36 Yamauchi T, Kamon J, Ito Y, Tsuchida A, Yokomizo T, Kita S: Cloning of adiponectin receptors that mediate antidiabetic metabolic effects. Nature 2003;423:762-769.

37 Maeda N, Funahashi T: Adiponectin knockout mice. Nippon Rinsho 2004;62:1067-1076.

38 Kubota N, Yano W, Kubota T, Yamauchi T, Itoh S, Kumagai H, Kozono H, Takamoto I, Okamoto S, Shiuchi T, Suzuki R, Satoh H, Tsuchida A, Moroi M, Sugi K, Noda T, Ebinuma H, Ueta Y, Kondo T, Araki E, Ezaki O, Nagai R, Tobe K, Terauchi Y, Ueki K, Minokoshi Y, Kadowak T: Adiponectin stimulates AMP-activated protein kinase in the hypothalamus and increases food intake. Cell Metab 2007;6:55-68.
$9 \mathrm{Hu}$ E, Liang P, Spiegelman BM: AdipoQ is a novel adipose-specific gene dysregulated in obesity. J Biol Chem 1996;271;10697-10703.

40 Yamauchi T, Kamon J, Waki H, Terauchi Y, Kubota N, Hara K, Mori Y, Ide T, Murakami K, Tsuboyama-Kasaoka N, Ezaki O, Akanuma Y, Gavrilova $\mathrm{O}$, Vinson $\mathrm{C}$, Reitman ML, Kagechika $\mathrm{H}$, Shudo K, Yoda M, Nakano Y, Tobe K, Nagai R, Kimura S, Tomita M, Froguel P, Kadowaki T: The fat-derived hormone adiponectin reverses insulin resistance associated with both lipoatrophy and obesity. Nat Med 2001;7:941-946.

41 Furukawa S, Fujita T, Shimabukuro M, Iwaki M, Yamada Y, Nakajima Y, Nakayama O, Makishima M, Matsuda M, Shimomura I: Increased oxidative stress in obesity and its impact on metabolic syndrome. J Clin Invest 2004;114:1752-1761.

42 Bruun JM, Lihn AS, Verdich C, Pedersen SB Toubro S, Astrup A, Richelsen B: Regulation of adiponectin by adipose tissue-derived cytokines: in vivo and in vitro investigations in humans. Am J Physiol Endocrinol Metab 2003;285:E527-533.

43 Berg AH, Combs TP, Du X, Brownlee M, Scherer PE: The adipocyte-secreted protein Acrp30 enhances hepatic insulin action. Nat Med 2001;7:947-953.

44 Mori Y, Otabe S, Dina C, Yasuda K, Populaire C, Lecoeur C, Vatin V, Durand E, Hara K, Okada T, Tobe K, Boutin P, Kadowaki T, Froguel P: Genome-wide search for type 2 diabetes in Japanese affected sib-pairs confirms susceptibility genes on $3 q, 15 q$, and $20 \mathrm{q}$ and identifies two new candidate loci on 7p and 11p. Diabetes 2002;51:1247-1255.

45 Hara K, Boutin P, Mori Y, Tobe K, Dina C, Yasuda K, Yamauchi T, Otabe S, Okada T, Eto K, Kadowaki H, Hagura R, Akanuma Y, Yazaki Y, Nagai R, Tanitama M, Matsubara K, Yoda M, Nakano Y, Kimura S, Tomita M, Ito C, Froguel P, Kadowaki T: Genetic variation in the gene encoding adiponectin is associated with an increased risk of type 2 diabetes in the Japanese population. Diabetes 2002;51:536-540

46 Lindsay RS, Funahashi T, Hanso RL, Matsuzawa Y, Tanaka S, Tataranni PA: Adiponectin and development of type 2 diabetes in the Pima Indian population. Lancet 2002;360:57-58.

47 Wang C, Mao X, Wang L, Liu M, Wetzel M, Guan KL, Dong LQ, Liu F: Adiponectin sensitizes insulin signalling by reducing p70 S6 kinase-mediated serine phosphorylation of IRS-1. J Biol Chem 2007;282:7991-7996.

48 Okamoto M, Ohara-Imaizumi M, Kubota N, Hashimoto S, Eto K, Kanno T, Kubota T, Wakui M, Nagai R, Noda M, Nagamatsu S, Kadowaki T: Adiponectin induces insulin secretion in vivo and in vitro at low glucose concentration. Diabetologia 2008;51:827-835.

49 Kubota N, Terauchi Y, Yamauchi T, Kubota T, Moroi M, Matsui J, Eto K, Yamashita T, Kamon J, Satoh H, Yano W, Froguel P, Nagai R, Kimura S, Kadowaki T, Noda T: Disruption of adiponectin causes insulin resistance and neointimal formation. J Biol Chem 2002;277:25863-25866.

50 Okamoto Y, Arita Y, Nishida M, Muraguchi M, Ouchi N, Takahashi M, Igura T, Inui Y, Kihara S, Nakamura T, Yamashita S, Miyagawa J, Funahashi T, Matsuzawa Y: An adipocyte-derived plasma protein, adiponectin, adheres to injured vascular walls. Horm Metab Res 2000;32:47-50.

51 Ouchi N, Kihara S, Arita Y, Maeda K, Kuriyama H, Okamoto Y, Hotta K, Nishida M, Takahashi M, Nakamura T, Yamashita S, Funahashi T, Matsuzawa Y: Novel modulator for endothelial adhesion molecules: adipocyte-derived plasma protein adiponectin. Circulation 1999;100:2473-2476. 
-52 Arita Y, Kihara S, Ouchi N, Maeda K, Kuriyama H, Okamoto Y, Kumada M, Hotta K, Nishida M, Takahashi M, Nakamura T, Shimomura I, Muraguchi M, Ohmoto Y, Funahashi T, Matsuzawa $\mathrm{Y}$ : Adipocyte-derived plasma protein adiponectin acts as a platelet-derived growth factor-BB-binding protein and regulates growth factor-induced common postreceptor signal in vascular smooth muscle cell. Circulation 2002;105:2893-2898.

53 Ouchi N, Kihara S, Arita Y, Nishida M, Matsuyama A, Okamoto Y, Ishigami M, Kuriyama H, Kishida K, Nishizawa H, Hotta K, Muraguchi M, Ohmoto Y, Yamashita S, Funahashi T, Matsuzawa Y: Adipocyte-derived plasma protein, adiponectin, suppresses lipid accumulation and class A scavenger receptor expression in human monocyte-derived macrophages. Circulation 2001;103:1057-1063.

54 Pischon T, Girman CJ, Hotamisligil GS, Rifai $\mathrm{N}, \mathrm{Hu}$ FB, Rimm EB: Plasma adiponectin levels and risk of myocardial infarction in men. JAMA 2004;291:1730-1737.

55 Schnabel R, Messow CM, Lubos E, Espinola-Klein C, Rupprecht HJ, Bickel C, Sinning C, Tzikas S, Keller T, Genth-Zotz S, Lackner KJ, Münzel TF, Blankenberg S: Association of adiponectin with adverse outcome in coronary artery disease patients: results from the AtheroGene study. Eur Heart J 2008;29:649-657.

D6 Lara-Castro C, Luo N, Wallace P, Klein RL, Garvey WT: Adiponectin multimeric complexes and the metabolic syndrome trait cluster. Diabetes 2006;55:249-259.

57 Von Eynatten M, Humpert PM, Bluemm A, Lepper PM, Hamann A, Allolio B, Naworth PP, Bierhaus A, Dugi KA: High-molecular weight adiponectin is independently associated with the extent of coronary artery disease in men. Atherosclerosis 2008;199:123-128.

58 Waki H, Yamauchi T, Kamon J, Ito Y, Uchida S, Kita S, Hara K, Hada Y, Vasseur F, Frogue P, Kimura S, Nagai R, Kadowaki T: Impaired multimerization of human adiponectin mutants associated with diabetes. Molecular structure and multimer formation of adiponectin. J Biol Chem 2003;278:40352-40363.

59 Schwartz S, Raskin P, Fonseca V, Graveline JF: Effect of troglitazone in insulin-treated patients with type II diabetes. N Engl J Med 1998;338:861-866.

60 Yilmaz MI, Sonmez A, Caglar K, Celik T, Yenicesu M, Eyjileten T, Acikel C, Oguz Y, Yavuz I, Vural A: Effect of antihypertensive agents on plasma adiponectin levels in hypertensive patients with metabolic syndrome. Nephrology (Carlton) 2007;12:147-153.

61 Nakamura T, Kodama Y, Takano H, Umetani K, Fujioka D, Saito Y: Increase in circulating levels of adiponectin after treatment with statin and fibrate in patients with coronary artery disease and hyperlipidemia. Atherosclerosis 2007;193:449-451.

62 Westphal S, Luley C: Preferential increase in highmolecular weight adiponectin after niacin. Atherosclerosis 2008;198:179-183.

63 Steppan CM, Bailey ST, Bhat S, Brown EJ, Banerjee RR, Wright CM, Patel HR, Ahima RS, Lazar MA: The hormone resistin links obesity to diabetes. Nature 2001;409:307-312.

64 Holcomb IN, Kabakoff RC, Chan B, Baker TW, Gurney A, Henzel W, Nelson C, Lowman HB, Wright BD, Skelton NJ, Frantz GD, Tumas DB, Peale FV Jr, Shelton DL, Hebert CC: FIZZ1, a novel cysteine-rich secreted protein associated with pulmonary inflammation, defines a new gene family. EMBO J 2000;19:4046-4055.
65 Aruna B, Ghosh S, Singh AK, Mande SC, Srinivas V, Chauhan R, Ehtesham NZ: Human recombinant resistin protein displays a tendency to aggregate by forming intermolecular disulfide linkages. Biochemistry 2003;42:10554-10559.

66 Azuma K, Katsukawa F, Oguchi S, Murata M, Yamazaki H, Shimada A, Saruta T: Correlation between serum resistin level and adiposity in obese individuals. Obes Res 2003;11:997-1001.

67 Silha JV, Krsek M, Skrha JV, Sucharda P, Nyomba BL, Murphy LJ: Plasma resistin, adiponectin and leptin levels in lean and obese subjects: correlations with insulin resistance. Eur J Endocrinol 2003;149: 331-335.

68 Way JM, Görgün CZ, Tong Q, Uysal KT, Brown KK, Harrington WW, Oliver WR Jr, Willson TM, Kliewer SA, Hotamisligil GS: Adipose tissue resistin expression is severely suppressed in obesity and stimulated by peroxisome proliferatoractivated receptor gamma agonists. J Biol Chem 2001;276:25651-25653.

69 Heilbronn LK, Rood J, Janderova L, Albu JB, Kelley DE, Ravussin E, Smith SR: Relationship between serum resistin concentrations and insulin resistance in nonobese, obese, and obese diabetic subjects. J Clin Endocrinol Metab 2004;89:18441848.

70 Beckers S, Peeters AV, de Freitas F, Mertens IL, Hendrickx JJ, Van Gaal LF, Van Hul W: Analysis of genetic variations in the resistin gene shows no associations with obesity in women. Obesity 2008;16:905-907.

71 Savage DB, Sewter CP, Klenk ES, Segal DG, Vidal-Puig A, Considine RV, O'Rahilly S: Resistin/ Fizz3 expression in relation to obesity and peroxisome proliferator-activated receptor-gamma action in humans. Diabetes 2001;50:2199-2202.

72 Michel MC, Beck-Sickinger A, Cox H, Doods HN, Herzog H, Larhammar D, Quirion R, Schwartz T, Westfall T: International Union of Pharmacology recommendations for the nomenclature of neuropeptide Y, peptide YY, and pancreatic polypeptide receptors. Pharmacol Rev 1998;50:143-150.

73 Adrian TE, Ferri GL, Bacarese-Hamilton AJ, Fuessl HS, Polak JM, Bloom SR: Human distribution and release of a putative new gut hormone, peptide YY. Gastroenterology 1985;89:1070-1077.

74 Ekblad E, Sundler F: Distribution of pancreatic polypeptide and peptide YY. Peptides 2002;23:251261.

75 Lin HC, Chey WY: Cholecystokinin and peptide YY are released by fat in either proximal or distal small intestine in dogs. Regul Pept 2003;114:131-135.

76 Oesch S, Rüegg C, Fischer B, Degen L, Beglinger $\mathrm{C}$ : Effect of gastric distension prior to eating on food intake and feelings of satiety in humans. Physiol Behav 2006;87:903-910.

77 Onaga T, Zabielski R, Kato S: Multiple regulation of peptide YY secretion in the digestive tract. Peptides 2002;23:279-290.

78 Batterham RL, Cowley MA, Small CJ, Herzog H, Cohen MA, Dakin CL, Wren AM, Brynes AE, Low MJ, Ghatei MA, Cone RD, Bloom SR: Gut hormone PYY(3-36) physiologically inhibits food intake. Nature 2002;418:650-654

79 Grandt D, Schimiczek M, Beglinger C, Layer P, Goebell H, Eysselein VE, Reeve JR Jr: Two molecular forms of peptide YY (PYY) are abundant in human blood: characterization of a radioimmunoassay recognizing PYY 1-36 and PYY 3-36. Regul Pept 1994;51:151-159.

80 Lin HC, Zhao XT, Wang L, Wong H: Fat-induced ileal brake in the dog depends on peptide YY. Gastroenterology 1996;110:1491-1495.
1 Allen JM, Fitzpatrick ML, Yeats JC, Darcy K, Adrian TE, Bloom SR: Effects of peptide YY and neuropeptide $\mathrm{Y}$ on gastric emptying in man. Digestion 1984;30:255-262.

82 Hoentjen F, Hopman WP, Jansen JB: Effect of circulating peptide $\mathrm{YY}$ on gallbladder emptying in humans. Scand J Gastroenterol 2001;36:1086-1091.

83 Abbott CR, Monteiro M, Small CJ, Sajedi A, Smith KL, Parkinson JR, Ghatei MA, Bloom SR: The inhibitory effects of peripheral administration of peptide YY(3-36) and glucagon-like peptide-1 on food intake are attenuated by ablation of the vagal-brainstem-hypothalamic pathway. Brain Res 2005;1044:127-131.

84 Schwartz MW, Woods SC, Porte D Jr, Seeley RJ, Baskin DG: Central nervous system control of food intake. Nature 2000;404:661-671.

85 Nonaka N, Shioda S, Niehoff ML, Banks WA: Characterization of blood-brain barrier permeability to PYY3-36 in the mouse. J Pharmacol Exp Ther 2003;306:948-953.

86 Keire DA, Mannon P, Kobayashi M, Walsh JH, Solomon TE, Reeve JR Jr: Primary structures of PYY, [Pro(34)]PYY, and PYY-(3-36) confer different conformations and receptor selectivity. Am J Physiol Gastrointest Liver Physiol 2000;279: G126-131.

87 Acuna-Goycolea C, van den Pol AN: Peptide YY (3-36) inhibits both anorexigenic proopiomelanocortin and orexigenic neuropeptide $\mathrm{Y}$ neurons: implications for hypothalamic regulation of energy homeostasis. J Neurosci 2005;25:10510-10519.

88 Batterham RL, Cohen MA, Ellis SM, Le Roux CW, Withers DJ, Frost GS, Ghatei MA, Bloom SR: Inhibition of food intake in obese subjects by peptide YY3-36. N Engl J Med 2003;349:941-948.

89 Riediger T, Bothe C, Becskei C, Lutz TA: Peptide YY directly inhibits ghrelin-activated neurons of the arcuate nucleus and reverses fasting-induced c-Fos expression. Neuroendocrinology 2004;79: 317-326.

90 Sloth B, Davidsen L, Holst JJ, Flint A, Astrup A: Effect of subcutaneous injections of PYY1-36 and PYY3-36 on appetite, ad libitum energy intake, and plasma free fatty acid concentration in obese males. Am J Physiol Endocrinol Metab 2007;293: E604-609.

91 Le Roux CW, Batterham RL, Aylwin SJ, Patterson M, Borg CM, Wynne KJ, Kent A, Vincent RP, Gardiner J, Ghatei MA, Bloom SR: Attenuated peptide YY release in obese subjects is associated with reduced satiety. Endocrinology 2006;147:3-8.

92 Ma L, Tataranni PA, Hanson RL, Infante AM, Kobes S, Bogardus C, Baier LJ: Variations in peptide $\mathrm{YY}$ and $\mathrm{Y} 2$ receptor genes are associated with severe obesity in Pima Indian men. Diabetes 2005;54:1598-1602.

93 Lavebratt C, Alpman A, Persson B, Arner P, Hoffstedt J: Common neuropeptide Y2 receptor gene variant is protective against obesity among Swedish men. Int J Obes (Lond) 2006;30:453-459.

94 Viardot A, Heilbronn LK, Herzog H, Gregersen S, Campbell LV: Abnormal postprandial PYY response in insulin sensitive nondiabetic subjects with a strong family history of type 2 diabetes. Int $\mathrm{J}$ Obes (Lond) 2008;32:943-948.

95 Zwirska-Korczala K, Konturek SJ, Sodowski M, Wylezol M, Kuka D, Sowa P, Adamczyk-Sowa M Kukla M, Berdowska A, Rehfeld JF, Bielanski W, Brzozowski T: Basal and postprandial plasma levels of PYY, ghrelin, cholecystokinin, gastrin and insulin in women with moderate and morbid obesity and metabolic syndrome. J Physiol Pharmacol 2007;58(suppl 1):13-35. 
-96 Misra M, Miller K, Tsai P, Gallagher K, Lin A, Lee N, Herzog D, Klibanski A: Elevated peptide YY levels in adolescent girls with anorexia nervosa. J Clin Endocrinol Metab 2006;91:1027-1033.

97 El-Salhy M, Suhr O, Danielsson A: Peptide YY in gastrointestinal disorders. Peptides 2002;23:397402.

98 Le Roux CW, Ghatei MA, Gibbs JS, Bloom SR: The putative satiety hormone PYY is raised in cardiac cachexia associated with primary pulmonary hypertension. Heart 2005;91:241-242.

99 Korner J, Bessler M, Cirilo LJ, Conwell IM, Daud A, Restuccia NL, Wardlaw SL: Effects of Rouxen-Y gastric bypass surgery on fasting and postprandial concentrations of plasma ghrelin, peptide YY, and insulin. J Clin Endocrinol Metab 2005;90:359-365.

100 Van den Hoek AM, Heijboer AC, Corssmit EP, Voshol PJ, Romijn JA, Havekes LM, Pijl H: PYY3-36 reinforces insulin action on glucose disposal in mice fed a high-fat diet. Diabetes 2004;53:1949-1952.

101 Boey D, Lin S, Karl T, Baldock P, Lee N, Enriquez $\mathrm{R}$, Couzens $\mathrm{M}$, Slack $\mathrm{K}$, Dallmann $\mathrm{R}$, Sainsbury A, Herzog H: Peptide YY ablation in mice leads to the development of hyperinsulinaemia and obesity. Diabetologia 2006;49:1360-1370.

102 Sloth B, Holst JJ, Flint A, Gregersen NT, Astrup A: Effects of PYY1-36 and PYY3-36 on appetite, energy intake, energy expenditure, glucose and fat metabolism in obese and lean subjects. Am J Physiol Endocrinol Metab 2007;292:E1062-1068.

-103 Stock S, Leichner P, Wong AC, Ghatei MA, Kieffer TJ, Bloom SR, Chanoine JP: Ghrelin, peptide YY, glucose-dependent insulinotropic polypeptide, and hunger responses to a mixed meal in anorexic, obese, and control female adolescents. J Clin Endocrinol Metab 2007;90:2161-2168.

104 Sileno AP, Brandt GC, Spann BM, Quay SC: Lower mean weight after 14 days intravenous administration peptide YY3-36 (PYY3-36) in rabbits. Int J Obes (Lond) 2006;30:68-72.

105 Halford JC: Obesity drugs in clinical development. Curr Opin Investig Drugs 2006;7:312-318.

106 Date Y, Kojima M, Hosoda H, Sawaguchi A, Mondal MS, Suganuma T, Matsukura S, Kangawa K, Nakazato M: Ghrelin, a novel growth-hormone-releasing acylated peptide, is synthesized in a distinct endocrine cell type in the gastrointestinal tracts of rats and humans. Endocrinology 2000;141:4255-4261.

-107 Gutierrez JA, Solenberg PJ, Perkins DR, Willency JA, Knierman MD, Jin Z, Witcher DR, Luo S, Onyia JE, Hale JE: Ghrelin octanoylation mediated by an orphan lipid transferase. Proc Natl Acad Sci U S A 2008;105:6320-6325.

108 Yang J, Brown MS, Liang G, Grishin NV, Goldstein JL: Identification of the acyltransferase that octanoylates ghrelin, an appetite-stimulating peptide hormone. Cell 2008;132:387-396.

109 Kojima M, Hosoda H, Date Y, Nakazato M, Matsuo H, Kangawa K: Ghrelin is a novel growth hormone releasing acylated peptide from stomach. Nature 1999;402:656-660.

110 Willesen MG, Kristensen P, Romer J: Co-localization of growth hormone secretagogue receptor and NPY mRNA in the arcuate nucleus of the rat. Neuroendocrinology 1999;70:306-316.

-111 Cummings DE, Purnell JQ, Frayo RS, Schmidova $\mathrm{K}$, Wisse BE, Weigle DS: A preprandial rise in plasma ghrelin levels suggests a role in meal initiation in humans. Diabetes 2001;50:1714-1719.

112 Cummings DE, Shannon MH: Roles for ghrelin in the regulation of appetite and body weight. Arch Surg 2003;138:389.
113 Tschöp M, Smiley DL, Heiman ML: Ghrelin induces adiposity in rodents. Nature 2000;407:908913

114 Wren AM, Seal LJ, Cohen MA, Brynes AE, Frost GS, Murphy KG, Dhillo WS, Ghatei MA, Bloom SR: Ghrelin enhances appetite and increases food intake in humans. J Clin Endocrinol Metab 2001;86:5992.

115 Sun Y, Wang P, Zheng H, Smith RG: Ghrelin stimulation of growth hormone release and appetite is mediated through the growth hormone secretagogue receptor. Proc Natl Acad Sci U S A 2003;101:4679-4684.

116 Toshinai K, Yamaguchi H, Sun Y, Smith RG, Yamanaka A, Sakurai T, Date Y, Mondal MS, Shimbara T, Kawagoe T, Murakami N, Miyazato M, Kangawa K, Nakazato M: Des-acyl ghrelin induces food intake by a mechanism independent of the growth hormone secretagogue receptor. Endocrinology 2006;147:2306-2314.

117 Theander-Carrillo C, Wiedmer P, Cettour-Rose P, Nogueiras R, Perez-Tilve D, Pfluger P, Castaneda TR, Muzzin P, Schürmann A, Szanto I, Tschöp MH, Rohner-Jeanrenaud F: Ghrelin action in the brain controls adipocyte metabolism. J Clin Invest 2006;116:1983-1993.

118 Arvat E, Maccario M, Di Vito L, Broglio F, Benso A, Gottero C, Papotti M, Muccioli G, Dieguez C, Casanueva FF, Deghenghi R, Camanni F, Ghigo $\mathrm{E}$ : Endocrine activities of ghrelin, a natural growth hormone secretagogue (GHS), in humans: comparison and interactions with hexarelin, a nonnatural peptidyl GHS, and GH-releasing hormone. J Clin Endocrinol Metab 2001;86:1169-1174.

119 Depoortere I, De Winter B, Thijs T, De Man J, Pelckmans P, Peeters T: Comparison of the gastroprokinetic effects of ghrelin, GHRP-6 and motilin in rats in vivo and in vitro. Eur J Pharmacol 2005;515:160-168.

120 Isgaard J, Barlind A, Johansson I: Cardiovascular effects of ghrelin and growth hormone secretagogues. Cardiovasc Hematol Disord Drug Targets 2008;8:133-137.

121 Tannous dit El Khoury D, Obeid O, Azar ST, Hwalla N: Variations in postprandial ghrelin status following ingestion of high-carbohydrate, high-fat, and high-protein meals in males. Ann Nutr Metab 2006;50:260-269.

122 Cummings DE, Weigle DS, Frayo RS, Breen PA, Ma MK, Dellinger EP, Purnell JQ: Plasma ghrelin levels after diet-induced weight loss or gastric bypass surgery. N Engl J Med 2002;346:1623-1630.

123 Tschöp M, Wawarta R, Riepl RL, Friedrich S, Bidlingmaier M, Landgraf R, Folwaczny C: Postprandial decrease of circulating human ghrelin levels. J Endocrinol Invest 2001;24:RC19-21.

124 Drazen DL, Vahl TP, D'Alessio DA, Seeley RJ, Woods SC: Effects of a fixed meal pattern on ghrelin secretion: evidence for a learned response independent of nutrient status. Endocrinology 2006;147:23-30

125 Shintani M, Ogawa Y, Ebihara K, Aizawa-Abe M, Miyanaga F, Takaya K, Hayashi T, Inoue G, Hosoda K, Kojima M, Kangawa K, Nakao K: Ghrelin, an endogenous growth hormone secretagogue, is a novel orexigenic peptide that antagonizes leptin action through the activation of hypothalamic neuropeptide $\mathrm{Y} / \mathrm{Y} 1$ receptor pathway. Diabetes 2001;50:227-232.

126 Banks WA, Tschöp M, Robinson SM, Heiman ML: Extent and direction of ghrelin transport across the blood-brain barrier is determined by its unique primary structure. J Pharmacol Exp Ther 2002;302:822-827.
127 Date Y, Murakami N, Toshinai K, Matsukura S, Niijima A, Matsuo H, Kangawa K, Nakazato M: The role of the gastric afferent vagal nerve in ghrelin-induced feeding and growth hormone secretion in rats. Gastroenterology 2002;123:1120-1128.

128 Yasuda T, Masaki T, Kakuma T, Yoshimatsu H: Centrally administered ghrelin suppresses sympathetic nerve activity in brown adipose tissue of rats. Neurosci Lett 2003;349:75-78.

129 Lawrence CB, Snape AC, Baudoin FM, Luckman SM: Acute central ghrelin and GH secretagogues induce feeding and activate brain appetite centers. Endocrinology 2002;143:155-162.

130 Cummings DE, Foster KE: Ghrelin-leptin tango in body-weight regulation. Gastroenterology 2003;124:1532-1535.

131 Kohno D, Nakata M, Maekawa F, Fujiwara K, Maejima Y, Kuramochi M, Shimazaki T, Okano H, Onaka T, Yada T: Leptin suppresses ghrelininduced activation of neuropeptide $\mathrm{Y}$ neurons in the arcuate nucleus via phosphatidylinositol 3-kinase- and phosphodiesterase 3-mediated pathway. Endocrinology 2007;148:2251-2263.

132 Saad MF, Bernaba B, Hwu CM, Jinagouda S, Fahmi S, Kogosov E, Boyadjian R: Insulin regulates plasma ghrelin concentration. J Clin Endocrinol Metab 2002;87:3997-4000.

133 McLaughlin T, Abbasi F, Lamendola C, Frayo RS, Cummings DE: Plasma ghrelin concentrations are decreased in insulin-resistant obese adults relative to equally obese insulin-sensitive controls. J Clin Endocrinol Metab 2004;89:1630-1635.

134 Paik KH, Jin DK, Song SY, Lee JE, Ko SH, Song SM, Kim JS, Oh YJ, Kim SW, Lee SH, Kim SH, Kwon EK, Choe YH: Correlation between fasting plasma ghrelin levels and age, body mass index (BMI), BMI percentiles, and 24-hour plasma ghrelin profiles in Prader-Willi syndrome. J Clin Endocrinol Metab 2004;89:3885-3889.

135 Tschöp M, Weyer C, Tataranni PA, Devanarayan V, Ravussin E, Heiman ML: Circulating ghrelin levels are decreased in human obesity. Diabetes 2001;50:707-709.

136 Cremonini F, Camilleri M, Vazquez Roque M, McKinzie S, Burton D, Baxter K, Zinsmeister AR: Obesity does not increase effects of synthetic ghrelin on human gastric motor functions. Gastroenterology 2006;131:1431-1439.

137 Morínigo R, Casamitjana R, Moizé V, Lacy AM, Delgado S, Gomis R, Vidal J: Short-term effects of gastric bypass surgery on circulating ghrelin levels. Obes Res 2004;12:1108-1116.

138 Neary NM, Small CJ, Wren AM, Lee JL, Druce MR, Palmieri C, Frost GS, Ghatei MA, Coombes RC, Bloom SR: Ghrelin increases energy intake in cancer patients with impaired appetite: acute, randomized, placebo-controlled trial. J Clin Endocrinol Metab 2004;89:2832-2836.

139 Muccioli G, Tschöp M, Papotti M, Deghenghi R, Heiman M, Ghigo E: Neuroendocrine and peripheral activities of ghrelin: implications in metabolism and obesity. Eur J Pharmacol 2002;440:235-254.

140 Xin Z, Serby MD, Zhao H, Kosogof C, Szczepankiewicz BG, Liu M, Liu B, Hutchins CW, Sarris KA, Hoff ED, Falls HD, Lin CW, Ogiela CA, Collins CA, Brune ME, Bush EN, Droz BA, Fey TA, Knourek-Segel VE, Shapiro R, Jacobson PB, Beno DW, Turner TM, Sham HL, Liu G: Discovery and pharmacological evaluation of growth hormone secretagogue receptor antagonists. J Med Chem 2006;49:4459-4469.

141 Moulin A, Ryan J, Martinez J, Fehrentz JA: Recent developments in ghrelin receptor ligands. ChemMedChem 2007;2:1242-1259. 